\title{
The Position and Tasks of International Organizations in the Labor Migration Management
}

\author{
Submitted 11/09/19, $1^{\text {st }}$ revision 05/10/19, $2^{\text {nd }}$ revision 30/10/19, accepted 22/11/19
}

Petrovskaya N.E. ${ }^{1}$

\begin{abstract}
:
Purpose: The purpose of this note is to present the main international organizations involved in the labor migration management, to reveal their position and to evaluate their work in migration macroeconomic processes, identify obstacles to effective control of labor migrants flows at the global level.

Design/Methodology/Approach: Methods of expert evaluations, comparison, generalization, classification and analysis were used in the study. The study is based on the legislation analysis of the International labor Organization and other specialized agencies of the United Nations. Findings: The author has investigated the position and tasks in labor force management of key international organizations dealing with labor migration at the global level. An important aspect of their activity is the comprehensive evaluation of migration processes, drawing up a global architecture of the migration, the relationship of the Sustainable Development Goals 2015-2030 with the population migration, as well as the establishment of a dialogue between different countries, the creation of international discussion platforms, the application of human rights norms to the regulation of the migration and the strengthening of the international legal regime in the field of migration. The author investigated the main trends in the global labor migration management, emphasizes the need for the formation of a multilevel migration management system carried out the analysis of the Global Compact for Safe, Regular and Orderly Migration.

Practical implications: The results of the research will contribute to study international organizations on the labor migration global management.

Originality/Value: Intergovernmental organizations is an important additional tool in building an international system of labor migration management. Donor and recipient countries of migrant workers, as well as international organizations often have different goals and objectives, but they are united by one global goal.
\end{abstract}

Keywords: Labor migration, international organizations, regular and orderly migration.

JEL Classification Codes: F01, F22, F53.

Paper Type: Research study: Migration.

\footnotetext{
${ }^{1}$ Senior Research Fellow, PhD in Economics, Institute for U.S. and Canadian Studies, Russian Academy of Sciences, Moscow, vitern@mail.ru
} 


\section{Introduction}

In the second decade of the XXIst century, the international labor migration changed radically. The world is facing new challenges requiring timely solutions. The migration situation in the world is fundamentally different. The labor migration has become global and requires coordinated international actions. The purpose of this article is to study the main international organizations involved in the labor migration management, to reveal their role in the migration macroeconomic processes, to evaluate the effectiveness of their work, identify obstacles to effective management of labor migration flows at the global level.

\section{Materials and Methods}

In recent years, the number of studies on migration has rapidly increased. Among the main "think tanks" of the world engaged in the study of the international migration are: Migration Policy Institute (United States), Brookings Institution (United States), Pew Research Centre (United States), Development Institute (United Kingdom), Friedrich Ebert Foundation (Germany), Bruegel (Belgium), Center for China and Globalization (China), Institute of Southeast Asian Studies - Yusof Ishak Institute (Singapore), Lowy Institute for International Policy (Australia), Overseas South African Institute of International Affairs (South Africa).

Key publications that reflect data on global trends in the labor migration are:

International Migration Report, World Migration Report, ILO Global Estimates on International Migrant Workers, Behind Closed Doors: Protecting and Promoting the Human Rights of Migrant Domestic Workers in an Irregular Situation.

This article uses the methods of the expert evaluation, comparison, generalization, classification and analysis to study the labor migration development.

\section{Results}

Today in the world there is taking place an unprecedented global movement of people. According to the latest available data, there are 164 million migrant workers in the world, 96 million of them are men and 68 million are women (ILO, 2018).

The most part of migrant workers (67.9\%) work in Upper-income countries, $18.6 \%$ work in Upper middle-income countries, $10.1 \%$ work in Lower middle income and only 3.4\% work in Low income (ILO, 2018). More than $71 \%$ of labor migrants are employed in the service sector, about $18 \%$ are in manufacturing and construction, $11 \%$ are in agriculture. Opportunities in the world are extremely unevenly redistributed. This inequality is a major driver of people's movement and carries enormous potential for the human development (Petrovskaya, Kozyr and Nasybullina, 2018). The 
proportion of international migrants considerably varies all over the world. For example, in the UAE it is $88.4 \%$, in Switzerland it is $9.4 \%$, in Australia it is $28.2 \%$, in the United States it is $14.5 \%$ (World Migration Report, 2018). Due to such high mobility of the population, there is a need for the formation of a global migration policy. It is important to apply interdisciplinary and multidisciplinary approaches.

When choosing a destination country, migrants rely, among other things, on various ratings of countries, assessing their global competitiveness. These ratings are formed by international organizations. The most extensive studies are the World Competitiveness Ranking (WCR) and the Global Competitiveness Index (GCI) (Kozyr, Petrovskaya and Zazimko, 2018). The role of international organizations in the labour migration management has increased in the XXI century. A key focus is the application of human rights norms to the regulation of the migration and the strengthening of the international legal regime in this field. Also, a very important direction is the comprehensive evaluation of migration processes, drawing up a global architecture of the migration, the relationship of the Sustainable Development Goals 2015-2030 with the population migration.

However, there are opinions that the activity of international organizations is not independent, it is influenced by the countries that contribute most of all to the budget of these organizations. UN General Secretary Kofi Annan drew attention to the issue of the migration in 2003 and called for the "global management" of migration processes in the world, which was the impetus for the creation of the Global Migration Group (GMG). To date, the Migration Group brings together $18 \mathrm{UN}$ agencies and the International organization for migration. The International labor organization (ILO) is the most important link in the UN system, coordinating the migration of labor resources in the world. It promotes the status of migrant workers by consistently upholding rights of workers regardless of their nationality and citizenship. It was founded 100 years ago; it is the oldest organization and one of the most representative international organizations. It consists of 187 states.

The International Organization for Migration (IOM) was established 68 years ago. It is an intergovernmental institution that, according to data of March 2019, brings together 173 countries and 8 countries-observers. Russia has the status of the observer. The IOM develops programs aimed at orderly planning of the migration of people; promotes the movement of skilled labor and their families, who can contribute to the development of the host country. It collects and analyzes data, makes recommendations, manages projects, works with governmental, non-governmental and intergovernmental partners. More than 11 thousand people work for the IOM worldwide, carrying out about 2300 projects, with operating costs of $\$ 1.5$ million. The structure of the IOM includes, among other things, 9 regional offices, their task is to develop regional strategies. The Global Migration Data Analysis Centre (GMDAC) has been established at IOM to provide comprehensive qualitative data on international migration trends (IOM, 2019). Within the IOM, there is the Development 
Fund that serves as a global resource for states-members eligible for assistance to develop capacity in the migration management, to meet the needs for "seed funding" for innovative and advanced initiatives. Priority projects include activities aimed at improving migration management practices and creating conditions for humane and orderly migration. About 700 IOM Development Fund projects are currently being implemented in 122 countries all over the world.

To display complete and reliable migration statistics, the IOM has created a Migration Data Portal (MDP, 2019). Through the foundation of the Association of migration research leaders formed on its base world's leading migration researchers from different geographical and thematic areas share their experiences and innovative solutions in migration issues to support the Global Compact (IOM, 2019).

The IOM has various labor migration programmes in 70 countries. The IOM's approach to the international labor migration is to promote the interaction between the labor migration and development, and to promote legitimate labor migration mechanisms as an alternative for the illegal migration, to develop policies that provide the effective protection and assistance to migrant workers and their families. The proportion of countries pursuing policies to increase the immigration of highly skilled personnel doubled from $22 \%$ in 2005 to $44 \%$ in 2015 . Globally, most states are either seeking to increase (44\%) or maintain $(41 \%)$ the current level of immigration of highly skilled workers. Only $4 \%$ of governments have policies to reduce the flow of highly skilled workers to their countries, while the remaining $11 \%$ have no policies (United Nations, 2017). At the initiative of the World Bank, the Global Knowledge Partnership on Migration and Development (KNOMAD) was established in 2013. It works closely with other international organizations in the field of the labor migration.

One of the tasks of international organizations is to establish a dialogue between states of different levels of the development. Among the most important discussion platforms is the Global Forum on Migration and Development. This forum has been held annually since 2007. It attracts more than 160 states and more than 45 different international organizations. Over the past period, the forum has been held in countries such as Belgium, Philippines, Greece, Mexico, Switzerland, Mauritius, Sweden, Turkey, Bangladesh, Germany-Morocco. There is an annual alternation of developed and developing countries. In 2019, the forum will be held in Ecuador. The forum systematically discusses issues related to the coherent policy and the development of the international migration (Global Forum, 2019). In 2018, the Global Compact for Safe, Regular and Orderly Migration (GCM) was adopted as a result of the global forum. The Global Compact for Migration was the first comprehensive agreement reached through intergovernmental negotiations and concluded under the auspices of the United Nations, which covers all the aspects of the international migration (UN General Assembly, 2018; Prytkova, 2017). 
It should be noted that the Global Contact is a framework document that has no legal obligations and it is aimed at developing international cooperation between countries. The IOM will serve as the coordinator of the Contact. The most relevant among 23 Goals stated in the Global compact are:

- The facilitate access to and flexibility of legal migration channels (Goal 5). In order to achieve this goal, it is planned to optimize educational opportunities, promote labor mobility and decent work for labor migrants.

- Promote fair, ethical and decent employment and work (Goal 6). In order to maximize the migrant labor socio-economic impact in donor and recipient countries, countries undertake to review existing employment mechanisms, protect all migrant workers from all the forms of the exploitation and abuse, and ensure decent working conditions.

- Investing in the skills development and promoting mutual recognition of skills, qualification and competencies (Goal 18). To achieve this goal, countries are committed to investing in innovative solutions that will promote the mutual recognition of the skills, qualification and competencies of migrant workers at all the skill levels, to ensure decent work in the context of the labor migration.

- The establishment of mechanisms for the transfer of social security entitlements and acquired benefits (Goal 22).

The Global compact implies that migrant workers of all the skill levels will be covered by the social protection system in the destination countries and will be able to enjoy material social security rights and acquired benefits in their countries of origin or in those countries where they leave due to the employment change (UN General Assembly, 2018). The Review forum on international migration is planned to be held every 4 years starting from 2022 in order to discuss issues and results of the implementation of the Global compact.

In the XXIst century, data collection on the international migration continues to be a challenge. In January 2018, the First International Forum on Migration Statistics (IFMS) was held. It was attended by more than 90 countries represented by international organizations, statistical agencies, academic institutions. The main objective of the forum was to mobilize expertise from a wide range of disciplines, such as Sociology, Demography, Statistics, Informatics, and to improve the collection and analysis of data on migrants.

To date, there are 4 main international legal instruments relating to migrant workers. One of the most important problems is that not all the countries of the world are ready to ratify them. In Table 1 more details are presented. 
Table 1. The status of the international instruments' ratification related to labor migration (International Migration Report, 2017)

\begin{tabular}{|c|c|c|c|c|}
\hline \multirow[t]{2}{*}{$\begin{array}{l}\text { The year of } \\
\text { adoption }\end{array}$} & \multirow{2}{*}{$\begin{array}{l}\text { The } \\
\text { year of } \\
\text { entry } \\
\text { into } \\
\text { force }\end{array}$} & \multirow[t]{2}{*}{ The name of the document } & \multicolumn{2}{|c|}{$\begin{array}{l}\text { Countries that have } \\
\text { ratified the international } \\
\text { legal act }\end{array}$} \\
\hline & & & Number & $\begin{array}{l}\text { Proportion, } \\
\%\end{array}$ \\
\hline 1949 & 1952 & $\begin{array}{l}\text { ILO Convention concerning } \\
\text { Migration for Employment (Revised } \\
\text { 1949) (No. 97) }\end{array}$ & 49 & 26 \\
\hline 1975 & 1978 & $\begin{array}{l}\text { ILO Convention concerning } \\
\text { Migrations in Abusive Conditions } \\
\text { and the Promotion of Equality of } \\
\text { Opportunity and Treatment of } \\
\text { Migrant Workers (Supplementary } \\
\text { Provisions) (No. 143) }\end{array}$ & 23 & 12 \\
\hline 1990 & 2003 & $\begin{array}{l}\text { International Convention on the } \\
\text { Protection of the Rights of All } \\
\text { Migrant Workers and Members of } \\
\text { Their Families }\end{array}$ & 51 & 26 \\
\hline 2011 & 2013 & $\begin{array}{l}\text { ILO Convention concerning Decent } \\
\text { Work for Domestic Workers (No. } \\
\text { 189) }\end{array}$ & 24 & 13 \\
\hline
\end{tabular}

As can be seen from the presented data, 95 countries have ratified at least one of the 4 instruments, accounting for 91 million migrant workers (35\%). It is important to note that conventions are often ratified only by donor countries of migrant workers, as this is a tool for them to protect their citizens. While recipient countries do not sign or ratify conventions, pursuing their own migration policy.

December 18 is the International Migrant Day. The UN General Secretary in his notes dedicated to Migrant Day regularly calls for ratifying the International Convention on the Protection of the Rights of All Migrant Workers and Members of Their Families of 1990 , but so far, only $26 \%$ of countries have ratified this convention. The role of international organizations is, among other things, to encourage countries to ratify international legal instruments.

According to experts, with the advent of the temporary and circular (circular) and permanent migration, which reflects a new kind of international labor mobility, migration patterns have become even more complex (LMP Guide, 2006). The migration in the form of cross-border or inter-state flows can be effectively managed only through the international cooperation. The development of the fair and rational labor migration policy and practice requires the dialogue among governments at all the levels, as well as the involvement of other key stakeholders, namely social partners (employers and trade unions) and civil society organizations (LMP Guide, 2006). 
The international migration is included in the 2030 agenda for Sustainable Development Goals. Eleven of seventeen goals contain objectives and indicators related to the migration. The main principle of the Agenda "no one will be forgotten" applies to all the people, including migrants. The labor migration targets include eradicating forced labor, ensuring safe and secure working conditions for all the workers, including migrant workers, reducing the cost of remittances for migrants, and other broader targets for all the migrants (Sustainable Development Goals, 2019).

\section{Conclusion}

Meeting labor needs is the main driver of countries' immigration policies, according to $68 \%$ of the states. According to the ILO data, the number of migrant workers was about three-quarters from all the international migrants of working age (15 years and older) all over the world in $2015.46 \%$ of the surveyed states also see the immigration policy as a tool to provide employment opportunities for their citizens (United Nations, 2017). The state migration policy of any state has limited instruments of influence on international labor flows. Intergovernmental organizations are important additional tools in building an international system of the labor migration management.

Despite the large amount of work done by international organizations, recipient states of migrant workers often do not consider international recommendations, and pursue policies based on their own vision of solving this issue. The main interaction at the global level is limited to short-term consultations that do not impose any obligations on the participants. Donor and recipient countries of migrant workers, as well as international organizations often have different goals and objectives, but they are united by one global goal. It is the orderly, predictable labor migration.

Challenges of the XXI century require the development and application of new methods of the labor migrant management, considering the experience gained earlier. It is necessary to form a multi-level migration management system. In this regard, the adoption of the Global Compact for Safe, Regular and Orderly Migration is an important step in strengthening cooperation in the field of the international migration.

\section{References:}

Global Forum on Migration and Development, 2019. Available at: http://www.gfmd.org/.

ILO. 2018. ILO Global Estimates on International Migrant Workers. Results and Methodology. International Labour Office, Geneva, available at: https://www.ilo.org/wcmsp5/groups/public/---dgreports/---dcomm/--qzr0pjdsatvgaxec580356hvacre8t7pc5538pauvm.

International Migration Report 2017. Available at:

https://www.un.org/en/development/desa/population/migration/publications/migrati onreport/docs/MigrationReport2017.pdf.

IOM. 2019. International Organization for Migration. Available at: https://www.iom.int/. 
Kozyr, N.S., Petrovskaya, N.E., Zazimko, V.L. 2018. Modern Approaches in Assessing Global Competitiveness. European Research Studies Journal, S2(21), 1034-1041.

LMP Guide. 2006. Guide for the Development of Effective Labour Migration Policy in countries of Origin and Destination. Available at: https://publications.iom.int/system/files/pdf/osce_iom_ilo_handbook_ru.pdf.

MDP. 2019. Migration Data Portal. The bigger picture. Available at: https://migrationdataportal.org.

Petrovskaya, N.E., Kozyr, N.S., Nasybullina, V.P. 2018. G20 Competitiveness in Human Development. European research studies journal, S2(21), 914-922.

Prytkova, I.Yu. 2017. Foreign Experience of Regulation of Migration Processes by the Example of the Migration Policy of Canada. European Research Studies Journal, 20(3A), 134-142.

Rupeika-Apoga, R., Romanova, I., Bule, L., Thalassinos, E.Y. 2019. The Impact of Population Ageing and Social Stratification: The Case of Latvia. International Journal of Economics and Business Administration, 7(1), 49-63.

Sustainable Development Goals. 2019. Available at: https://www.un.org/sustainabledevelopment/inequality/.

UN General Assembly. 2018. Intergovernmental Conference to Adopt the Global Compact for Safe, Orderly and Regular Migration. Marrakech, Morocco, available at: https://undocs.org/en/A/CONF.231/3.

UN PD. 2017. United Nations, Department of Economic and Social Affairs, Population Division. International Migration Policies: Data Booklet (ST/ESA/SER.A/395), available at:

https://www.un.org/en/development/desa/population/publications/pdf/policy/interna tional_migration_policies_data_booklet.pdf.

World Migration Report. 2018. Available at: http://publications.iom.int/system/files/pdf/wmr_2018_en.pdf. 